Institute of $\mathbf{F}_{\text {ood and }} \mathbf{A}$ gricultural $\mathbf{S}_{\text {ciences }}$

\title{
Florida Solid and Hazardous Waste Regulation Handbook: Local Government Structuring ${ }^{1}$
}

\section{Michael T. Olexa, Aaron Leviten, and Kelly Samek ${ }^{2}$ \\ What Do I Need to Know about Local Governments?}

The laws of local governments are called ordinances. These local laws have the authority of the state behind them and you can be prosecuted for violating them, much the same as state laws. Local governments have procedural protections similar to those of the state, but these may vary among the local governments. The legislature can also affect local policy and issues through the passage of special laws that apply only to a certain locale.

\section{What Is the Structure of Local Government?}

The structure of local government varies. Counties and cities are usually headed by elected commissions. These commissions are the authority of the local government. Just as the state and federal legislatures delegate the details, so do local commissions. Usually, running the day-to-day aspects of government is delegated to a professional manager and local agencies. As a result, these agencies may have the power to make decisions.

\section{How Are Local Govenrments Involved in Waste Management?}

Local governments are very involved in waste management. They frequently administer collection and disposal facilities. In addition, each county:

- has a resource recovery and management program.

- performs hazardous waste assessments on a regular basis.

- maintains records of small quantity generators.

- is involved with a Regional Planning Council (RPC), (RPCs coordinate on many issues, including waste management).

Local Emergency Planning Committees (LEPs) are not directly involved with local governments but do play an important part in waste management. LEPs are responsible for:

- developing emergency plans for dealing with spills.

1. This is EDIS document FE456, a publication of the Department of Food and Resource Economics, Florida Cooperative Extension Service, UF/IFAS, University of Florida, Gainesville, FL. Published December 2003. Please visit the EDIS website at http://edis.ifas.ufl.edu.

2. Michael T. Olexa, Professor in the Department of Food and Resource Economics and Director of the Agricultural Law Center, Florida Cooperative Extension Service, UF/IFAS, University of Florida, Gainesville, FL, and Member of the Florida Bar and Chair of the Agricultural Law Committee of the Florida Bar; Aaron Leviten, Attorney in Orlando and guest lecturer on pesticide litigation at the University of Florida; and Kelly Samek, 2003 graduate of the Levin College of Law at the University of Florida.

The Institute of Food and Agricultural Sciences is an equal opportunity/affirmative action employer authorized to provide research, educationa information and other services only to individuals and institutions that function without regard to race, color, sex, age, handicap, or national origin. For information on obtaining other extension publications, contact your county Cooperative Extension Service office. Florida Cooperative Extension Service/Institute of Food and Agricultural Sciences/University of Florida/Christine Taylor Waddill, Dean. 
- coordinating local and state authorities under federal and state right-to-know laws.

\section{Acknowledgments}

The authors are indebted to the personnel of both state and federal agencies who gave their time and advice in the preparation of this handbook. The authors are also indebted to the following University of Florida personnel for a review and critique of the first draft of this publication: Dr. Thomas Dean, Pesticide Education Specialist, and Dr. Norman Nesheim, Pesticide Information Coordinator. Special recognition is also due to Mr. Richard Budell of the Office of Agricultural Water Policy of the Florida Department of Agriculture and Consumer Services for providing funds for the development of this handbook.

This handbook is designed to provide an accurate, current, and authoritative summary of the principal Florida laws that directly or indirectly relate to agriculture. It should provide a basic overview of the many rights and responsibilities farmers and farmland owners have under Florida laws. The reader is provided information about these rights and responsibilities and the appropriate contacts for more detailed information. However, the reader should be aware that because the laws, administrative rulings, and court decisions on which this publication is based are subject to constant revision, portions of this publication could become outdated at any time. Many details of cited laws are also left out due to space limitations.

This handbook is distributed with the understanding that the authors are not engaged in rendering legal or other professional advice and the information contained herein should not be regarded or relied upon as a substitute for professional advice. It is not all-inclusive in providing information to achieve compliance with laws and regulations governing the practice of agriculture. For these reasons, the use of these materials by any person constitutes an agreement to hold harmless the authors, UF/IFAS, the Agricultural Law Center, and the University of Florida for any liability claims, damages, or expenses that may be incurred by any person as a result of reference to or reliance upon the information contained in this publication. 